\title{
Research Article \\ Effect of different levels of phosphorus on growth and yield of cowpea varieties in Dang, Nepal
}

\author{
Anjeela Aryal ${ }^{1 *}$, Ashbin Kumar Devkota ${ }^{1}$, Krishna Aryal ${ }^{1}$ and Mohan Mahato ${ }^{1}$ \\ ${ }^{1}$ Institute of Agriculture and Animal Science, Prithu Technical College, Deukhuri, Dang, Nepal \\ *Correspondence: angeela.aryal@gmail.com \\ *ORCID: https://orcid.org/0000-0002-2999-3144 \\ Received: September 20 2020; Accepted: November 27, 2020; Published: January 01, 2021
}

(c) Copyright: Aryal et al. (2021).

\section{(c) (1) (9)}

4.0International License.

\begin{abstract}
Variety having proper response to phosphorus for proper nutrient uptake and the optimum level of phosphorus for higher yield may be a way of increasing production and productivity in the context of Nepal. This experiment was carried out in Lamahi Municpality, Dang district of the Province no: 5, inner terai region of Nepal during the rainy season, 2019. The objective of the experiment was to study the effect of different phosphorus level on growth and development of different varieties of cowpea. The experiment was laid out in two factorial RCBD with two varieties (Aakash and Prakash) and five phosphorus level (0kg ha ${ }^{-1}, 20 \mathrm{~kg} \mathrm{ha}^{-1}, 40$ $\mathrm{kg} \mathrm{ha}^{-1}, 60 \mathrm{~kg} \mathrm{ha}^{-1}$ and $\left.80 \mathrm{~kg} \mathrm{ha}^{-1}\right)$. The result revealed that variety Aakash showed the significantly higher yield of fresh pod (15.99 tha ${ }^{-1}$ ) and yield attributing parameters like number of leaves at 45 DAS (35.22), leaf area at 45 DAS $\left(70.23 \mathrm{~cm}^{2}\right)$, pod diameter $(0.77 \mathrm{~cm})$, total number of fresh pods per plant $(44.85)$ than Prakash variety (yield; 12.25 tha $^{-1}$ ). The parameters like number of branches and pod length were not affected by the variety used. In addition, the different level of $\mathrm{P}$ also affects the yield of the fresh pod of different varieties. The P level $40 \mathrm{kgha}^{-1}$ reported highest yield of fresh pod $\left(20.18 \mathrm{tha}^{-1}\right.$ and showed significantly higher number of leaves (38.9), number of branches (23.48), plant height $(88.78 \mathrm{~cm})$, leaf area $\left(81.89 \mathrm{~cm}^{2}\right)$, pod length $(17.76 \mathrm{~cm})$, pod diameter $(0.79 \mathrm{~cm})$ and total number of fresh pods per plant $(55.19)$ whereas control produced the lowest total yield of fresh pod (8.33 t ha $\mathrm{t}^{-1}$ ), control (30.99) and $80 \mathrm{~kg} \mathrm{P} \mathrm{ha}^{-1}$ (30.86) produced the least number of leaves, control produced the least number of branches $(17.31)$, control $(63.77 \mathrm{~cm})$ and $80 \mathrm{~kg} \mathrm{P} \mathrm{ha}^{-1}(67.83)$ produced the shortest plant, $80 \mathrm{~kg} \mathrm{P} \mathrm{ha}^{-1}$ produced the minimum leaf area $\left(51.09 \mathrm{~cm}^{2}\right)$,control produced least pod length $(14.3$ $\mathrm{cm})$, pod diameter $(0.74 \mathrm{~cm})$, total number of fresh pods (34.29). Similarly, interaction of Aakash and phosphorus dose $40 \mathrm{~kg} \mathrm{ha}^{-1}$ produced significantly maximum number of leaves (43.07) and total yield of fresh pods $\left(23.33\right.$ tha $\left.^{-1}\right)$. The results of the experiment revealed that variety Aakash with the phosphorus level $40 \mathrm{~kg}$ $\mathrm{ha}^{-1}$ seems the more profitable in Terai and inner Terai condition of Nepal. However, the results need to be confirmed for other varieties used by farmers in the region.
\end{abstract}

Keywords: Cowpea, Development, Growth, Phosphorus level, Yield

Correct citation: Aryal, A., Devkota, A.K., Aryal, K., \& Mahato, M. (2021). Effect of different levels of phosphorus on growth and yield of cowpea varieties in Dang, Nepal. Journal of Agriculture and Natural Resources, 4(1), 62-78.

DOI: https://doi.org/10.3126/janr.v4i1.33228

\section{INTRODUCTION}

Cowpea (Vigna unguiculata) is a warm season crop originated from Africa and belongs to leguminous family from the genus Vigna. It can adapt heat, dry and sandy conditions but is highly susceptible to frost (FAO, 2004). It is mainly used as a grain crop, animal fodder or as a vegetable. Mature, dry cowpea seed contains about 23 to $25 \%$ total protein, $57 \%$ carbohydrates, $1.3 \%$ fat and $3.5 \%$ minerals. It is also considered as poor man's meat (Ileke et 
$a l ., 2012)$. It also appears as an important crop in sustainable soil fertility management as it can fix upto $88 \mathrm{~kg} \mathrm{~N} \mathrm{ha}^{-1}$ (Fatokun et al., 2002).

In Nepal, Cowpea is given less importance among the grain legumes and considered as the minor crop. Cowpea cultivation covers about 3657 ha with the production of $36321 \mathrm{t}$ and productivity of only $9.93 \mathrm{t} \mathrm{ha}^{-1}$ in Nepal (MoALD, 2018/2019). The production scenario of cowpea in developed countries are better than that of the under developed countries due to the use of the responsive input, efficient and production technology. The under developed countries have low production due to low input and labour intensive production system.

Various nutrients play an essential role for growth and development of cowpea. Being a leguminous crop it can fix nitrogen itself but requires additional phosphorus application which is the limiting factor for plant growth (Magadlela et al., 2016; Pérez-Fernández et al., 2017). Phosphorus application governs several nutrients in cowpea leaves (Kang and Nangju, 1983) and seed (Omueti \& Oyenuga, 1970). Similarly phosphorus addition to plant growing in poor soils helps in the increment of plant growth, nodulation and biomass production (Robson, 1983; Magadlela et al., 2016; Pérez-Fernández et al., 2017), $\mathrm{N}_{2}$ fixation (Stevens et al., 2019; Vardien et al., 2014; Amba et al., 2013), also influences the efficiency of rhizobium-legume symbiosis (Haruna \& Aliyu, 2011), flower initiation, seed and fruit development (Ndakidemi \& Dakora, 2007).

Varieties selection has also impact on the productivity of cowpea, which is associated with varietal characteristics like management practices, time of sowing, nutritional requirements, cropping time, input requirements for varieties. As the importance of cowpea production is increasing, many varieties have been developed to reduce the problem of low yield. As a result many inputs like fertilizer are being used to increase the production. The application of chemical fertilizers, are not sound or as per recommendation (Maskey et al., 2000). So continuous application of those acidifying fertilizers over along period of time may cause detrimental effect on soil. So proper dose of NPK and other fertilizers should be use in the crop field.

Low yield in production of cowpea indicates low use of inputs like quality seed, fertilizer and irrigation. Low yield may be due to the yield gap between farmer field and attainable yield. In Nepal the production of cowpea is low due to the cowpea is kept among the minor legumes and application of fertilizer is done haphazardly. The increasing population may reduce the land for the agriculture production. Therefore the only way to increase the production is to use proper inputs and technology for better yield. So, the proper use of inputs and technology can increase the productivity of cowpea. Suitability of varieties to a particular climate is most important factors for determining yield, the GE interaction should be maintain to high level. The variety that have proper response to fertilizer (NPK) for proper nutrient uptake is highly necessary for enhancing the yield. So it is important to find out the correct dose of phosphorus for maximum yield and proper nodulation development in cow pea. This research was undertaken to determine the different level of phosphorus needed for maximum yield in Lamahi, Deukhuri, Dang, inner terai of Western Nepal. 
Journal of Agriculture and Natural Resources (2021) 4(1): 62-78

ISSN: 2661-6270 (Print), ISSN: 2661-6289 (Online)

DOI: https://doi.org/10.3126/janr.v4i1.33228

\section{MATERIALS AND METHODS}

\section{Experimental Location}

The experiment was conducted in the farmer's field of Bangaun, Lamahi municipality, ward no.3 of Dang district from August to November, 2019. The experimental site was situated at $410 \mathrm{~km}$ west from Kathmandu, the capital of Nepal. Geographically it is located at $27.8625^{\circ}$ $\mathrm{N}$ latitude and $82.5443^{\circ} \mathrm{E}$ longitude at the elevation of 261 masl. This location falls in inner terai region of Province no. 5 of Nepal. The soil of the experimental site was silty loam having slightly acidic $\mathrm{pH}(6.67)$, low organic matter $(2.1 \%)$, medium total nitrogen $(0.10 \%)$, medium available phosphorus $\left(45 \mathrm{~kg} \mathrm{ha}^{-1}\right)$ and medium available potassium $\left(190.78 \mathrm{~kg} \mathrm{ha}^{-1}\right)$. Deukhuri's climate is nearly tropical and it is well watered by the river as well as possessing abundant groundwater.

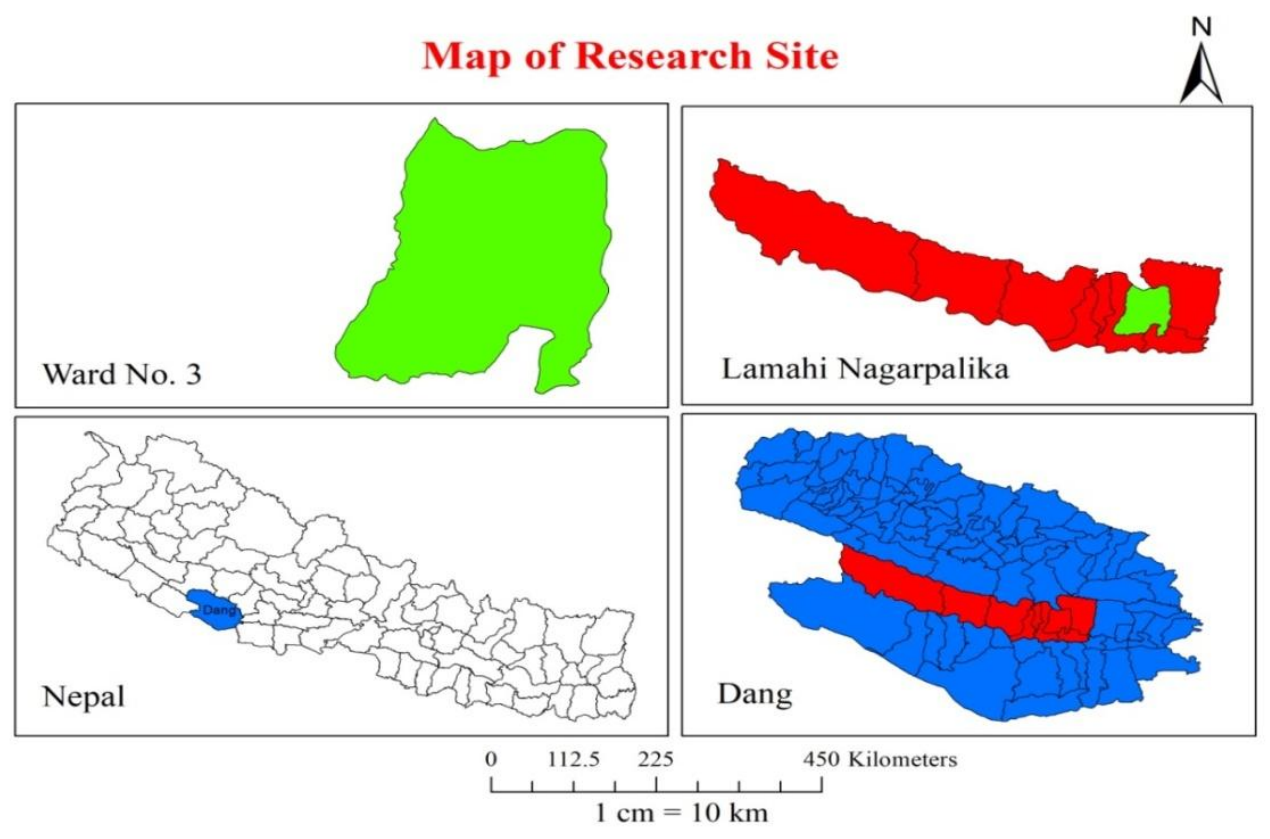

Figure 1.Map of experimental site

\section{Experimental design and treatment factors}

The experiment was conducted in two factorial RCBD design with two varieties and five phosphorus doses and was replicated thrice. Total area of the plot was $296.1 \mathrm{~m}^{2}$. Area of each treatment plot was $4.5 \mathrm{~m}^{2}(2.5 \mathrm{~m} \times 1.8 \mathrm{~m})$ with $0.5 \mathrm{~m}$ spacing between the treatment plots and $1 \mathrm{~m}$ in between the replication. There were 5 rows and 6 columns in each plot consisting of spacing of $30 \mathrm{~cm} \times 15 \mathrm{~cm}$ and 30 plants.

Table 1. Different factors used in the experiment

\begin{tabular}{lll}
\hline S. N. & Factors & Symbol \\
\hline Variety & & \\
\hline 1. & Aakash & V1 \\
2. & Prakash & V2 \\
\hline Phosphorus level $\left(\mathrm{kg} \mathrm{ha}^{-1}\right)$ & & F1 \\
\hline 1. & 0 & F2 \\
2. & 20 & F3 \\
3. & 40 & F4 \\
4. & 60 & F5 \\
5. & 80 & \\
\hline
\end{tabular}


Journal of Agriculture and Natural Resources (2021) 4(1): 62-78

ISSN: 2661-6270 (Print), ISSN: 2661-6289 (Online)

DOI: https://doi.org/10.3126/janr.v4i1.33228

Table 2. Different treatment combinations used in the experiment

\begin{tabular}{lll}
\hline Treatment number & Treatment combination & Symbol \\
\hline T1 & Aakash $+0 \mathrm{~kg} \mathrm{P} \mathrm{ha}^{-1}$ & V1F1 \\
T2 & Aakash $+20 \mathrm{~kg} \mathrm{P} \mathrm{ha}^{-1}$ & V1F2 \\
T3 & Aakash $+40 \mathrm{~kg} \mathrm{P} \mathrm{ha}^{-1}$ & V1F3 \\
T4 & Aakash $+60 \mathrm{~kg} \mathrm{P} \mathrm{ha}^{-1}$ & V1F4 \\
T5 & Aakash $+80 \mathrm{~kg} \mathrm{P} \mathrm{ha}^{-1}$ & V1F5 \\
T6 & Prakash $+0 \mathrm{~kg} \mathrm{P} \mathrm{ha}^{-1}$ & V2F1 \\
T7 & Prakash $+20 \mathrm{~kg} \mathrm{P} \mathrm{ha}^{-1}$ & V2F2 \\
T8 & Prakash $+40 \mathrm{~kg} \mathrm{P} \mathrm{ha}^{-1}$ & V2F3 \\
T9 & Prakash $+60 \mathrm{~kg} \mathrm{P} \mathrm{ha}^{-1}$ & V2F4 \\
T10 & Prakash $+80 \mathrm{~kg} \mathrm{P} \mathrm{ha}^{-1}$ & V2F5 \\
\hline
\end{tabular}

\section{Planting Materials and Cultural Practices}

Variety Aakash and Prakash were used for the experiment which were collected from Nepal Agricultural Research Station, Khajura, Banke. The variety is recommended for terai and inner terai domain of Nepal. The seeds were hydroprimed one day before sowing and all the damaged seeds were removed.

Well decomposed Farm Yard Manure (FYM) was applied in the plots @ 6 t/ha before 20 days of sowing during ploughing the field. Fertilizer Nitrogen, Phosphorus and Potassium were applied through Urea $(46 \% \mathrm{~N})$, SSP $\left(16 \% \mathrm{P}_{2} \mathrm{O}_{5}\right)$ and MOP $\left(60 \% \mathrm{~K}_{2} \mathrm{O}\right)$. Full dose of Nitrogen and Potassium were applied before final land preparation as basal dose in every plot. The recommended dose of nitrogen and potassium for cowpea cultivation is $20 \mathrm{~kg} \mathrm{ha}^{-1}$ (MoALD, 2019). Phosphorus dose was applied as per our treatment plan as basal dose.

The sowing of cowpea was done with planting geometry of $50 \mathrm{~cm} \times 30 \mathrm{~cm}$ in flat bed method. Light irrigation was done immediately after sowing. Further, Cowpea was slightly irrigated during flowering and pod formation stages. Manual weeding was done at 15 and 30 days after sowing to protect the crop from weed infestation. Chloropyriphos $50 \%$ and Cypermethrin 5\% EC were used for controlling insects such as aphids, grasshoppers, leaf hoppers and pod borers during vegetative as well as pod formation stage. Thinning and transplanting were done after 1 week of sowing. The pods were harvested manually three times at 60,75 and 90 days after sowing.

\section{Data Collection and analysis}

\section{Plant Parameters}

Randomly five plant samples were selected and tagged to record the data of crop growth parameters such as number of leaves, number of branches, plant height $(\mathrm{cm})$, leaf area $\left(\mathrm{cm}^{2}\right)$. Trifoliate leaves had been counted as a single leaf. Plant height was determined using the scale by measuring the distance from soil surface to the tip of leaf. Leaf area was measured by taking three leaves, two of them being the lateral leaflets and one of them being the central leaflet, which were sampled randomly from the sampled plants. Length of the leaf was measured along the mid-rib and breadths of the leaf were measured at three positions. The length and average width of the leaves were multiplied to obtain the leaf area of each leaf. The average area of three leaves was used as the leaf area of each individual plant. Similarly, Yield parameters such as pod diameter $(\mathrm{cm})$, pod length $(\mathrm{cm})$, number of fresh pods and yield of the fresh pod $(\mathrm{g})$ were recorded at the time of harvest. Pod diameter was measured by using vernier caliper. 
All the data from the experimental plot collected was subjected to analysis of variance (ANOVA). When the F-values were found to be significant, the treatment means were separated by Least Significant Difference (LSD) at 5\% probability level (Shrestha, 2019).In addition, simple correlation analysis was run between selected parameters. Microsoft word 2007 was used for word processing; MS excels for tables, graphs and simple statistical analysis. R-package was used for statistical analysis and SPSS for correlation determination among yield attributing characters.

\section{Design of ANOVA table}

Table 3. Design of ANOVA table of the research design used in the experiment

\begin{tabular}{llllll}
\hline Source of variation & Df & Sum of Sq. & M.S.S & F value & Pr(>F) \\
\hline Replication $(\mathrm{R})$ & $(\mathrm{r}-1)=2$ & & & \\
Variety $(\mathrm{V})$ & $(\mathrm{v}-1)=1$ & & & \\
P level & $(\mathrm{f}-1)=4$ & & & \\
Variety X P level & $(\mathrm{v}-1)(\mathrm{f}-1)=4$ & & & \\
Error & $(\mathrm{r}-1)(\mathrm{vf}-1)=18$ & & & \\
Total & $(\mathrm{rvf}-1)=29$ & & & \\
\hline
\end{tabular}

\section{RESULTS AND DISCUSSION}

\section{Effect of different level of phosphorus on growth parameters of cowpea varieties Number of leaves per plant}

The number of leaves per plant was significantly $(\mathrm{P}<0.001)$ influenced by varieties (Table 4$)$ at various days (15 and 45 DAS), however the number of leaves weren't influenced at 30 DAS. The Aakash variety recorded the highest number of leaves at 15 DAS (2.61) and 45 DAS (35.22) whereas Prakash variety recorded the lowest number of leaves in both days. Similarly, the number of leaves per plant was significantly $(\mathrm{P}<0.001)$ influenced by the different level of P level at various days 15 DAS, 30 DAS and 45 DAS (Table 5). The $40 \mathrm{~kg}$ $\mathrm{ha}^{-1} \mathrm{P}$ recorded the highest number of leaves in all 15 DAS (1.83), 30 DAS (24.77) and 45 DAS (38.9) whereas the control recorded the lowest number of leaves in all DAS. The interaction between varieties of cowpea used and phosphorus treatment significantly influenced the number of leaves $(\mathrm{P}>0.05)$ at 15 DAS and 45 DAS. The interaction of Aakash and phosphorus level40 $\mathrm{kg} \mathrm{ha}^{-1}$ produced highest number of leaves at 15 DAS (3.2) and 45 DAS (43.07) and the interaction effect of Aakash and phosphoruslevel60 kg ha ${ }^{-1}$ also produced statistically similar number of leaves at 45 DAS (39.47).

Similarly, the minimum number of leaves were produced by interaction effect of Prakash and controlled condition (2.1) and interaction effect of Prakash and phosphorus level of $20 \mathrm{~kg} \mathrm{ha}^{-1}$ (2.13)at 15 DAS and the interaction effect of Aakash and $80 \mathrm{~kg} \mathrm{P}^{-1}$ (30.58), Prakash and control (29.38) and Prakash and $20 \mathrm{~kg} \mathrm{P} \mathrm{ha}^{-1}$ (30.8) produced the least number of leaves at 45 DAS which are statistically similar (Table 5).Thosago (2015) found significant effects of the soil $\mathrm{P}$ levels on the number of leaves and similar findings were observed in research conducted by Nkaa et al. (2014) where $40 \mathrm{~kg} \mathrm{ha}^{-1}$ rate consistently produced the greatest number of leaves and the interaction between varieties of cowpea used and phosphorus treatment was also significant. The greater number of leaves in cowpea may be due to the application of $\mathrm{P}$ which increases the plant growth by increasing development of meristematic tissue. 
Journal of Agriculture and Natural Resources (2021) 4(1): 62-78

ISSN: 2661-6270 (Print), ISSN: 2661-6289 (Online)

DOI: https://doi.org/10.3126/janr.v4i1.33228

Table 4.Effect of different level of phosphorus on number of leaves at different time interval of cowpea varieties in Dang, Nepal during 2019.

\begin{tabular}{|c|c|c|c|}
\hline \multirow[t]{2}{*}{ Treatment } & \multicolumn{3}{|c|}{ Number of leaves } \\
\hline & 15 DAS & 30 DAS & 45 DAS \\
\hline \multicolumn{4}{|c|}{ Factor A (Varieties) } \\
\hline Aakash & $2.61 \mathrm{a}$ & 21.01 & $35.22 \mathrm{a}$ \\
\hline Prakash & $2.23 \mathrm{~b}$ & 19.45 & $31.45 \mathrm{~b}$ \\
\hline SEM $( \pm)$ & 0.15 & 1.34 & 1.90 \\
\hline LSD & 0.14 & 1.76 & 1.7 \\
\hline F-test & $* * *$ & NS & $* * *$ \\
\hline \multicolumn{4}{|c|}{ Phosphorus level $\left(\mathrm{kg} \mathrm{ha}^{-1}\right)$} \\
\hline 0 & $2.18 \mathrm{c}$ & $17.23 \mathrm{c}$ & $30.99 \mathrm{c}$ \\
\hline 20 & $2.22 \mathrm{c}$ & $19.82 \mathrm{bc}$ & $33.1 \mathrm{bc}$ \\
\hline 40 & $2.83 \mathrm{a}$ & $24.77 \mathrm{a}$ & $38.9 \mathrm{a}$ \\
\hline 60 & $2.48 \mathrm{~d}$ & $20.5 \mathrm{~b}$ & $35.33 \mathrm{~b}$ \\
\hline 80 & $2.40 \mathrm{bc}$ & $18.83 \mathrm{bc}$ & $30.86 \mathrm{c}$ \\
\hline Grand Mean & 2.42 & 20.23 & 33.84 \\
\hline $\operatorname{SEM}( \pm)$ & 0.09 & 0.85 & 1.20 \\
\hline LSD & 0.22 & 2.79 & 2.68 \\
\hline F-test & $* * *$ & $* * *$ & $* * *$ \\
\hline $\mathrm{CV} \%$ & 7.53 & 11.37 & 6.53 \\
\hline
\end{tabular}

Treatments means followed by the common letter or letters within the column are not significantly different among each other based on LSD at 5\% level of significance. $L S D=$ Least significant difference, SEM = Standard error of mean, $C V=$ Coefficient of variation, NS= Non significant and $*=$ Significant at 0.05 level, $* *=$ Significant at 0.01 level and $* * *=$ Significant at 0.001 level

Table 5. Interaction effect of different level of phosphorus and varieties of cowpea on number of leaves at different time interval in Dang, Nepal during 2019.

\begin{tabular}{lll}
\hline Treatment & Number of leaves & \\
\cline { 2 - 3 } & 15DAS & 45DAS \\
\hline Factor A ${ }^{\times}$Factor B & & $32.6 \mathrm{bcd}$ \\
\hline Aakash ${ }^{\times}$F1 & $2.27 \mathrm{cde}$ & $35.4 \mathrm{~b}$ \\
Aakash ${ }^{\times}$F2 & $2.30 \mathrm{cde}$ & $43.07 \mathrm{a}$ \\
Aakash ${ }^{\times}$F3 & $3.20 \mathrm{a}$ & $39.47 \mathrm{a}$ \\
Aakash ${ }^{\times}$F4 & $2.77 \mathrm{~b}$ & $30.58 \mathrm{~d}$ \\
Aakash ${ }^{\times}$F5 & $2.53 \mathrm{bc}$ & $29.38 \mathrm{~d}$ \\
Prakash ${ }^{\times}$F1 & $2.1 \mathrm{e}$ & $30.8 \mathrm{~d}$ \\
Prakash ${ }^{\times}$F2 & $2.13 \mathrm{e}$ & $34.73 \mathrm{bc}$ \\
Prakash ${ }^{\times}$F & $2.47 \mathrm{bcd}$ & $31.2 \mathrm{~cd}$ \\
Prakash $\times$ F4 & $2.2 \mathrm{de}$ & $31.13 \mathrm{~cd}$ \\
Prakash ${ }^{\times}$F5 & $2.27 \mathrm{cde}$ & 33.84 \\
\hline Grand Mean & 2.42 & 1.47 \\
SEM $( \pm)$ & 0.11 & 3.79 \\
LSD & 0.31 & $*$ \\
F-test & $*$ & 6.53 \\
CV\% & 7.53 &
\end{tabular}

Treatments means followed by the common letter or letters within the column are not significantly different among each other based on LSD at 5\% level of significance. $L S D=$ Least significant difference, SEM = Standard error of mean, $C V=$ Coefficient of variation, NS= Non significant and *= Significant at 0.05 level, $* *=$ Significant at 0.01 level and $* * *=$ Significant at 0.001 level

\section{Number of branches per plant}

There was no significant effect of the variety on the number of branches per plant. Phosphorus had significant $(\mathrm{P}<0.001)$ effect on the number of branches per plant at 45 DAS whereas there was no significant effect of phosphorus doses on the number of branches at 15 DAS and 30 DAS. Significantly higher branches per plant (23.48) were recorded in plots 
Journal of Agriculture and Natural Resources (2021) 4(1): 62-78

ISSN: 2661-6270 (Print), ISSN: 2661-6289 (Online)

DOI: https://doi.org/10.3126/janr.v4i1.33228

applied with $40 \mathrm{~kg} \mathrm{P} \mathrm{ha}^{-1}$ at $45 \mathrm{DAS}$ and the control produced the least number of branches at 45 DAS (17.31)(Table 6). The result of present investigation in terms of number of branches corroborate the findings of Ayodele and Oso (2014), Muhammed et al. (2013) and Namakka et al. (2017) who reported that total number of branches per plant increased with phosphorus application of $40 \mathrm{~kg} \mathrm{P} \mathrm{ha}^{-1}$ while the control produced the least number of branches per plant. Similarly our result also corroborate the finding obtained by Alhassan Bawa (2020) and Daramy (2017) where variety had no significant $(\mathrm{P}>0.05)$ effect on the number of branches of cowpea at $\mathrm{P}$ levels of $0,20,40$, and $60 \mathrm{~kg} \mathrm{P}_{2} \mathrm{O}_{5} \mathrm{ha}^{-1}$. Slow release of phosphatic fertilizers may be the reason for significant results at the later sampling dates. The production of more lateral buds which later developed into branches may be due to positive effect of phosphorus which enhances cell division and elongation.

Table 6. Effect of different level of phosphorus on number of branches at different time interval of cowpea varieties in Dang, Nepal during 2019.

\begin{tabular}{llll}
\hline Treatment & Number of branches & & \\
\cline { 2 - 4 } & 15 DAS & 30 DAS & 45 DAS \\
\hline Factor A (Varieties) & & & 19.76 \\
\hline Aakash & 0.03 & 3.78 & 19.67 \\
Prakash & 0.0 & 3.54 & 1.14 \\
\hline SEM $( \pm)$ & 0.03 & 0.34 & NS \\
\hline LSD & NS & NS & \\
F-test & NS & & $17.31 \mathrm{c}$ \\
\hline Phosphorus level $\left(\mathrm{kg} \mathrm{ha}^{-1}\right)$ & & 3.12 & $19.2 \mathrm{bc}$ \\
\hline 0 & 0.07 & 3.38 & $23.48 \mathrm{a}$ \\
20 & 0.0 & 4.42 & $20.23 \mathrm{~b}$ \\
40 & 0.0 & 3.75 & $18.36 \mathrm{bc}$ \\
60 & 0.0 & 3.63 & 19.72 \\
80 & 0.0 & 3.66 & 0.72 \\
\hline Grand Mean & 0.01 & 0.21 & 2.24 \\
SEM $( \pm)$ & 0.02 & NS & $* * *$ \\
LSD & NS & NS & 9.37 \\
F-test & NS & 20.06 & CV\% \\
\hline
\end{tabular}

Treatments means followed by the common letter or letters within the column are not significantly different among each other based on LSD at 5\% level of significance. $L S D=$ Least significant difference, SEM = Standard error of mean, $C V=$ Coefficient of variation, NS= Non significant and *= Significant at 0.05 level, $* *=$ Significant at 0.01 level and $* * *=$ Significant at 0.001 level

\section{Plant height}

Both treatments varieties and phosphorus doses are found to significantly $(\mathrm{P}<0.05)$ affect the plant height (Table 7).At 15 DAS $(25.4 \mathrm{~cm}), 30$ DAS $(53.32 \mathrm{~cm})$ and 45 DAS $(79.16 \mathrm{~cm})$, Variety Aakash attained the highest plant height whereas Prakash attained the least height in all days. Similarly, phosphorus level, $20 \mathrm{~kg} \mathrm{P} \mathrm{ha}^{-1}$ produced the tallest plant at 15 DAS (28.25 $\mathrm{cm}), 30$ DAS $(55.97 \mathrm{~cm})$ and 45 DAS $(88.78 \mathrm{~cm})$. The controlled condition produced the shortest plant at 15 DAS $(22.08 \mathrm{~cm}), 30$ DAS $(49.07 \mathrm{~cm})$ and 45 DAS $(63.77 \mathrm{~cm})$ and $80 \mathrm{~kg}$ $\mathrm{P} \mathrm{ha}^{-1}$ at $45 \mathrm{DAS}$ also produced the shortest plant among all treatments. The findings were supported by work of Namakka et al. (2017) and Nkaa et al. (2014), where $39 \mathrm{~kg} \mathrm{P} \mathrm{ha-1}$ produced significantly $(\mathrm{P}<0.05)$ taller plants than the control which could be attributed to the fact that in shoot and root tips where metabolism is high and cell division is rapid due to which plant height is increased, phosphorus is required in large quantities. The differences in plant height in varieties may be due to their genetic effect. 
Journal of Agriculture and Natural Resources (2021) 4(1): 62-78

ISSN: 2661-6270 (Print), ISSN: 2661-6289 (Online)

DOI: https://doi.org/10.3126/janr.v4i1.33228

Table 7. Effect of different level of phosphorus on plant height at different time interval of cowpea varieties in Dang, Nepal during 2019.

\begin{tabular}{|c|c|c|c|}
\hline \multirow[t]{2}{*}{ Treatment } & \multicolumn{3}{|c|}{ Plant Height $(\mathrm{cm})$} \\
\hline & $15 \mathrm{DAS}$ & $30 \mathrm{DAS}$ & $45 \mathrm{DAS}$ \\
\hline \multicolumn{4}{|c|}{ Factor A (Varieties) } \\
\hline Aakash & $25.4 \mathrm{a}$ & $53.32 \mathrm{a}$ & $79.16 \mathrm{a}$ \\
\hline Prakash & $23.94 \mathrm{~b}$ & $50.45 \mathrm{~b}$ & $70.94 \mathrm{~b}$ \\
\hline SEM $( \pm)$ & 1.09 & 1.37 & 4.44 \\
\hline LSD & 1.31 & 1.67 & 3.73 \\
\hline F-test & $*$ & $* *$ & $* * *$ \\
\hline \multicolumn{4}{|c|}{ Phosphorus level $\left(\mathrm{kg} \mathrm{ha}^{-1}\right)$} \\
\hline 0 & $22.08 \mathrm{c}$ & $49.07 \mathrm{c}$ & $63.77 \mathrm{c}$ \\
\hline 20 & $24.23 \mathrm{~b}$ & $50.15 \mathrm{bc}$ & $77.64 \mathrm{~b}$ \\
\hline 40 & $28.25 \mathrm{a}$ & $55.97 \mathrm{a}$ & $88.78 \mathrm{a}$ \\
\hline 60 & $24.64 b$ & $51.9 \mathrm{~b}$ & $77.24 \mathrm{~b}$ \\
\hline 80 & $24.14 \mathrm{bc}$ & $52.33 \mathrm{~b}$ & $67.83 \mathrm{c}$ \\
\hline Grand Mean & 24.67 & 51.88 & 75.05 \\
\hline LSD & 2.07 & 2.64 & 5.89 \\
\hline $\mathrm{CV} \%$ & 6.92 & 4.19 & 6.47 \\
\hline $\operatorname{SEM}( \pm)$ & 0.69 & 0.87 & 2.81 \\
\hline F-test & $* * *$ & $* * *$ & $* * *$ \\
\hline
\end{tabular}

\section{Leaf Area}

The leaf area was significantly $(\mathrm{P}<0.01)$ influenced by varieties at various days (15 DAS and 45 DAS), however the leaf area wasn't influenced at 30 DAS.

Table 8. Effect of different level of phosphorus on leaf area at different time interval of cowpea varieties in Dang, Nepal during 2019.

\begin{tabular}{llll}
\hline Treatment & Leaf Area $\left(\mathrm{cm}^{2}\right)$ & & \\
\cline { 2 - 4 } & 15 DAS & 30 DAS & \\
\hline Factor A (Varieties) & & & $70.23 \mathrm{a}$ \\
\hline Aakash & $18.69 \mathrm{a}$ & 56.54 & $58.26 \mathrm{~b}$ \\
Prakash & $15.72 \mathrm{~b}$ & 51.68 & 5.79 \\
\hline SEM $( \pm)$ & 1.81 & 4.64 & 5.75 \\
\hline LSD & 1.77 & NS & $* * *$ \\
F-test & $* *$ & NS & $58.74 \mathrm{bc}$ \\
\hline Phosphorus level $\left(\mathrm{kg} \mathrm{ha}^{-1}\right)$ & & & $63.67 \mathrm{~b}$ \\
\hline 0 & $12.86 \mathrm{~d}$ & $43.88 \mathrm{c}$ & $81.89 \mathrm{a}$ \\
20 & $15.73 \mathrm{c}$ & $54.51 \mathrm{abc}$ & $66.1 \mathrm{~b}$ \\
40 & $23.03 \mathrm{a}$ & $64.01 \mathrm{a}$ & $51.09 \mathrm{c}$ \\
60 & $18.86 \mathrm{~b}$ & $56.79 \mathrm{ab}$ & 64.3 \\
80 & $15.53 \mathrm{~cd}$ & $51.26 \mathrm{bc}$ & 9.1 \\
\hline Grand Mean & 17.20 & 54.09 & 11.66 \\
LSD & 2.79 & 12.13 & 3.67 \\
CV\% & 13.38 & 18.49 & $* * *$ \\
SEM $( \pm)$ & 1.15 & 2.93 & $*$ \\
F-test & $* * *$ & $*$ & . \\
\hline
\end{tabular}

Treatments means followed by the common letter or letters within the column are not significantly different among each other based on LSD at 5\% level of significance. $L S D=$ Least significant difference, SEM = Standard error of mean, $C V=$ Coefficient of variation, NS= Non significant and *= Significant at 0.05 level, $* *=$ Significant at 0.01 level and $* * *=$ Significant at 0.001 level 
Journal of Agriculture and Natural Resources (2021) 4(1): 62-78

ISSN: 2661-6270 (Print), ISSN: 2661-6289 (Online)

DOI: https://doi.org/10.3126/janr.v4i1.33228

The Aakash variety recorded the highest leaf area at 15 DAS $\left(18.69 \mathrm{~cm}^{2}\right)$ and 45 DAS $(70.23$ $\mathrm{cm}^{2}$ ) whereas Prakash recorded the lowest leaf area at both days. Similarly, phosphorus doses also significantly $(\mathrm{P}<0.05)$ affected the leaf area per plant at different intervals of time (Table 8) where $40 \mathrm{~kg} \mathrm{ha}^{-1}$ produced the highest leaf area at all 15 DAS $\left(23.03 \mathrm{~cm}^{2}\right), 30$ DAS $(64.01$ $\left.\mathrm{cm}^{2}\right)$ and 45 DAS $\left(81.89 \mathrm{~cm}^{2}\right)$ whereas control produced the least leaf area at 15 DAS (12.86 $\left.\mathrm{cm}^{2}\right), 30$ DAS $\left(43.88 \mathrm{~cm}^{2}\right)$ and $80 \mathrm{~kg} \mathrm{P} \mathrm{ha}^{-1}$ produced least leaf area at 45 DAS (51.09 $\mathrm{cm}^{2}$ ). The findings is similar to the result obtained by Namakka et al. (2017) and Nkaa et al. (2014) which showed that phosphorus level had significant effect on leaf area. As P is mobile in plants and highly concentrated in places of cell division, it may enhance leaf area.

\section{Pod length and diameter}

Varieties were found to non-significantly affect the length of pod of cowpea. Similarly, the pod length was significantly $(\mathrm{P}<0.001)$ influenced by phosphorus level where $40 \mathrm{~kg} \mathrm{P} \mathrm{ha}{ }^{-1}$ produced the longest pod $(17.7593 \mathrm{~cm})$ whereas control treatment produced the shortest pod $(14.2982 \mathrm{~cm}) .($ Table 9$)$.

Table 9. Effect of different level of phosphorus on pod length and pod diameter at different time interval of cowpea varieties in Dang, Nepal during 2019.

\begin{tabular}{lll}
\hline Treatment & Pod Length $(\mathrm{cm})$ & Pod Diameter $(\mathrm{cm})$ \\
\hline Factor A (Varieties) & & \\
\hline Aakash & 16.05 & $0.77 \mathrm{a}$ \\
Prakash & 15.62 & $0.76 \mathrm{~b}$ \\
\hline SEM $( \pm)$ & 0.54 & 0.01 \\
\hline LSD & NS & 0.01 \\
F-test & NS & $*$ \\
\hline Phosphorus level $\left(\mathrm{kg} \mathrm{ha}^{-1}\right)$ & & \\
\hline 0 & $14.3 \mathrm{c}$ & $0.74 \mathrm{c}$ \\
20 & $15.62 \mathrm{~b}$ & $0.76 \mathrm{~b}$ \\
40 & $17.76 \mathrm{a}$ & $0.79 \mathrm{a}$ \\
60 & $16.11 \mathrm{~b}$ & $0.76 \mathrm{~b}$ \\
80 & $15.39 \mathrm{~b}$ & $0.76 \mathrm{bc}$ \\
\hline Grand Mean & 15.83 & 0.76 \\
LSD & 0.79 & 0.02 \\
CV $\%$ & 4.13 & 1.67 \\
SEM $( \pm)$ & $0 . .34$ & 0.005 \\
F-test & $* * *$ & $* * *$ \\
\hline Treatmens
\end{tabular}

Treatments means followed by the common letter or letters within the column are not significantly different among each other based on LSD at 5\% level of significance. $L S D=$ Least significant difference, SEM = Standard error of mean, $C V=$ Coefficient of variation, $N S=$ Non significant and $*=$ Significant at 0.05 level, **= Significant at 0.01 level and $* * *=$ Significant at 0.001 level

Pod diameter was significantly $(\mathrm{P}<0.05)$ influenced by the varieties (Table 9$)$. The variety Aakash produced the highest pod diameter $(0.7687 \mathrm{~cm})$ and Prakash produced the least pod diameter $(0.76 \mathrm{~cm})$. Similarly, the pod diameter was significantly $(\mathrm{P}<0.001)$ influenced by phosphorus level where phosphorus level $40 \mathrm{~kg} \mathrm{ha}^{-1}$ produced the highest pod diameter $(0.7873 \mathrm{~cm})$ whereas control treatment produced the least pod diameter $(0.7443 \mathrm{~cm})$. Similar findings were observed in research conducted by Thosago (2015), Karikari et al. (2015), Nkaa et al.(2014), Akhtar et al. (2003) and Bunker et al. (2018) supported by the work of Thosago,2015; Karikari et al., 2015 and Nkaa et al., 2014 where P significantly increased the pod length of cowpea. This may be due to the optimum $\mathrm{P}$ level which increases the photosynthetic efficiency of crop leading to production of longer and larger pods. 
Journal of Agriculture and Natural Resources (2021) 4(1): 62-78

ISSN: 2661-6270 (Print), ISSN: 2661-6289 (Online)

DOI: https://doi.org/10.3126/janr.v4i1.33228

\section{Number of fresh pods per plant}

The number of fresh pods per plant at various days 60 DAS, 75 DAS and 90 DAS were significantly $(\mathrm{P}<0.05)$ influenced by the varieties (Table 10). Aakash produced the maximum number of fresh pods per plant at 60 DAS (19.1733), 75 DAS (14.48) and 90 DAS (11.1933) whereas Prakash produced the lowest number of fresh pods at all days. Similarly, The number of fresh pods were significantly $(\mathrm{P}<0.001)$ affected by the phosphorus level where phosphorus level $40 \mathrm{~kg} \mathrm{ha}^{-1}$ had produced the maximum number of fresh pods per plant at 60 DAS (23.7), 75 DAS (16.1) and 90 DAS (15.3917) whereas the control treatment produced the minimum number of fresh pods per plant at 60 DAS (14.73), 75 DAS (12.67) and 90 DAS (6.90). This result is in conformity with the result obtained by the Dhital et al.(1997) where there was a significant effect of variety $(\mathrm{P}<0.05)$ for number of pods per plant and Aakash produced 12\% more pods than Prakash.

Table 10. Effect of different level of phosphorus on number of fresh pods per plant at different time interval of cowpea varieties in Dang, Nepal during 2019.

\begin{tabular}{lllll}
\hline Treatment & \multicolumn{3}{l}{ Number of fresh pods (per plant) } & \\
\cline { 2 - 4 } & $60 \mathrm{DAS}$ & $75 \mathrm{DAS}$ & $90 \mathrm{DAS}$ & Total \\
\hline Factor A (Varieties) & & & & \\
\hline Aakash & $19.17 \mathrm{a}$ & $14.48 \mathrm{a}$ & $11.19 \mathrm{a}$ & $44.85 \mathrm{a}$ \\
Prakash & $17.6 \mathrm{~b}$ & $13.12 \mathrm{~b}$ & $9.36 \mathrm{~b}$ & $40.08 \mathrm{~b}$ \\
\hline SEM $( \pm)$ & 1.48 & 0.65 & 1.39 & 3.28 \\
\hline LSD & 1.09 & 0.56 & 1.45 & 1.70 \\
F-test & $* *$ & $* * *$ & $*$ & $* * *$ \\
\hline Phosphorus level $\left(\mathrm{kg} \mathrm{ha}^{-1}\right)$ & & & $6.90 \mathrm{c}$ & $34.29 \mathrm{e}$ \\
\hline 0 & $14.73 \mathrm{c}$ & $12.67 \mathrm{c}$ & $9.33 \mathrm{~b}$ & $41.19 \mathrm{c}$ \\
20 & $18.23 \mathrm{~b}$ & $13.63 \mathrm{~b}$ & $15.39 \mathrm{a}$ & $55.19 \mathrm{a}$ \\
40 & $23.7 \mathrm{a}$ & $16.1 \mathrm{a}$ & $10.73 \mathrm{~b}$ & $44.63 \mathrm{~b}$ \\
60 & $19.9 \mathrm{~b}$ & $14.0 \mathrm{~b}$ & $9.03 \mathrm{bc}$ & $37.0 \mathrm{~d}$ \\
80 & $15.37 \mathrm{c}$ & $12.6 \mathrm{c}$ & 10.28 & 42.46 \\
\hline Grand Mean & 18.39 & 13.8 & 0.88 & 2.07 \\
SEM $( \pm)$ & 0.93 & 0.41 & 2.29 & 2.69 \\
LSD & 1.73 & 0.89 & $* * *$ & $* * *$ \\
F-test & $* * *$ & $* * *$ & 18.36 & 5.23 \\
CV\% & 7.77 & 5.3 & & \\
\hline
\end{tabular}

Treatments means followed by the common letter or letters within the column are not significantly different among each other based on LSD at 5\% level of significance. $L S D=$ Least significant difference, SEM = Standard error of mean, $C V=$ Coefficient of variation, NS= Non significant and *= Significant at 0.05 level, $* *=$ Significant at 0.01 level and $* * *=$ Significant at 0.001 level

Similarly, the results of present investigation in terms of number of fresh pods per plant corroborate the findings of Singh et al. (2011), Haruna and Usman (2013), Ndor et al. (2012), Nyoki et al. (2013) and Karikari et al. (2015) who reported significant increase in pod number of cowpea in response to phosphorus application. This may be due to the existence of higher phosphate level which causes greater leaf expansion and ultimately high photosynthetic rate allowing the plants to allocate large amount of carbohydrates in reproductive areas and increases the production of pods.

\section{Fresh pod yield per plant}

The fresh pod yield per plant was significantly $(\mathrm{P}<0.05)$ influenced by varieties at various days 60 DAS, 75 DAS and 90 DAS (Table 11). The Aakash variety recorded the highest fresh pod per plant at 60 DAS (94.05g), 75 DAS (60.06g) and 90 DAS (85.86g). Similarly, the fresh pod yield per plant was significantly $(\mathrm{P}<0.001)$ influenced by the different level of $\mathrm{P}$ 
Journal of Agriculture and Natural Resources (2021) 4(1): 62-78

ISSN: 2661-6270 (Print), ISSN: 2661-6289 (Online)

DOI: https://doi.org/10.3126/janr.v4i1.33228

at various days $60 \mathrm{DAS}, 75 \mathrm{DAS}$ and $90 \mathrm{DAS}$. The $40 \mathrm{~kg} \mathrm{P}^{-1}$ produced the highest yield of fresh pod per plant at 60 DAS (109.67g), 75 DAS $(88.03 \mathrm{~g})$ and 90 DAS (105g) whereas the control recorded the lowest yield of fresh pod per plant in all days.

Table 11. Effect of different level of phosphorus on fresh pod yield at different time interval of cowpea varieties in Dang, Nepal during 2019.

\begin{tabular}{|c|c|c|c|c|}
\hline \multirow[t]{2}{*}{ Treatment } & \multicolumn{4}{|c|}{ Fresh pod yield (g per plant) } \\
\hline & 60 DAS & $75 \mathrm{DAS}$ & 90 DAS & Total \\
\hline \multicolumn{5}{|c|}{ Factor A (Varieties) } \\
\hline Aakash & $94.05 \mathrm{a}$ & $60.06 \mathrm{a}$ & $85.86 \mathrm{a}$ & $239.98 \mathrm{a}$ \\
\hline Prakash & $81.68 \mathrm{~b}$ & $38.66 \mathrm{~b}$ & $63.35 \mathrm{~b}$ & $183.69 \mathrm{~b}$ \\
\hline SEM $( \pm)$ & 8.71 & 10.48 & 11.70 & 28.88 \\
\hline LSD & 9.48 & 1.87 & 7.79 & 12.92 \\
\hline F-test & $*$ & $* * *$ & $* * *$ & $* * *$ \\
\hline \multicolumn{5}{|c|}{ Phosphorus level $\left(\mathrm{kg} \mathrm{ha}^{-1}\right)$} \\
\hline 0 & $64.03 \mathrm{c}$ & $26.7 \mathrm{e}$ & $34.15 \mathrm{~d}$ & $124.88 \mathrm{e}$ \\
\hline 20 & $89.53 b$ & $44.63 \mathrm{c}$ & $71.97 \mathrm{c}$ & $206.13 \mathrm{c}$ \\
\hline 40 & $109.67 \mathrm{a}$ & $88.03 \mathrm{a}$ & $105 \mathrm{a}$ & $302.7 \mathrm{a}$ \\
\hline 60 & $103.3 \mathrm{~b}$ & $57.87 \mathrm{~b}$ & $88.67 \mathrm{~b}$ & $249.83 \mathrm{~b}$ \\
\hline 80 & $72.8 \mathrm{c}$ & $29.6 \mathrm{~d}$ & $73.23 \mathrm{c}$ & $175.63 \mathrm{~d}$ \\
\hline Grand Mean & 87.87 & 49.37 & 74.60 & 211.83 \\
\hline $\operatorname{SEM}( \pm)$ & 5.51 & 6.63 & 7.40 & 18.26 \\
\hline LSD & 14.99 & 2.95 & 12.31 & 20.42 \\
\hline F-test & $* * *$ & $* * *$ & $* * *$ & $* * *$ \\
\hline $\mathrm{CV} \%$ & 14.07 & 4.93 & 13.60 & 7.95 \\
\hline
\end{tabular}

Treatments means followed by the common letter or letters within the column are not significantly different among each other based on LSD at 5\% level of significance. $L S D=$ Least significant difference, SEM = Standard error of mean, $C V=$ Coefficient of variation, $N S=$ Non significant and $*=$ Significant at 0.05 level, $* *=$ Significant at 0.01 level and $* * *=$ Significant at 0.001 level

Table 12. Interaction effect of different level of phosphorus and varieties of cowpea on fresh pod yield at different time interval of cowpea varieties in Dang, Nepal during 2019.

\begin{tabular}{|c|c|c|c|}
\hline \multirow[t]{2}{*}{ Treatment } & \multicolumn{3}{|c|}{ Yield of fresh pod (g per plant) } \\
\hline & 75DAS & 90DAS & Total \\
\hline \multicolumn{4}{|c|}{ Factor $\mathrm{A}^{\times}$Factor $\mathrm{B}$} \\
\hline Aakash $^{\times}$F1 & $34.93 \mathrm{de}$ & $38.5 \mathrm{f}$ & $142.77 \mathrm{~g}$ \\
\hline Aakash $\times$ F2 & $53.07 \mathrm{c}$ & 77.93 cde & $226.87 \mathrm{~cd}$ \\
\hline Aakash $\times$ F3 & $103.60 \mathrm{a}$ & $128.60 \mathrm{a}$ & $350.53 \mathrm{a}$ \\
\hline Aakash $\times$ F4 & $74.26 \mathrm{~b}$ & $99.60 \mathrm{~b}$ & $283.73 \mathrm{~b}$ \\
\hline Aakash $\times$ F5 & $34.47 \mathrm{de}$ & $84.67 \mathrm{bc}$ & $196 \mathrm{ef}$ \\
\hline Prakash $^{\times} \mathrm{F} 1$ & $18.47 \mathrm{e}$ & $29.80 \mathrm{f}$ & $107 \mathrm{~h}$ \\
\hline Prakash ${ }^{\times} \mathrm{F} 2$ & 36.2 cde & 66 de & $185.40 \mathrm{f}$ \\
\hline Prakash $\times$ F3 & $72.46 \mathrm{~b}$ & $81.4 \mathrm{~cd}$ & $254.87 \mathrm{bc}$ \\
\hline Prakash ${ }^{\times}$F4 & $41.47 \mathrm{~cd}$ & 77.73 cde & $215.93 \mathrm{de}$ \\
\hline Prakash $\times$ F5 & $24.73 \mathrm{de}$ & $61.80 \mathrm{e}$ & $155.27 \mathrm{~g}$ \\
\hline Grand Mean & 49.36 & 74.60 & 211.84 \\
\hline $\operatorname{SEM}( \pm)$ & 8.12 & 9.06 & 22.37 \\
\hline LSD & 17.74 & 17.40 & 28.90 \\
\hline F-test & $* * *$ & $*$ & $*$ \\
\hline CV\% & 20.95 & 13.60 & 7.96 \\
\hline
\end{tabular}

Treatments means followed by the common letter or letters within the column are not significantly different among each other based on LSD at 5\% level of significance. $L S D=$ Least significant difference, SEM = Standard error of mean, $C V=$ Coefficient of variation, $N S=$ Non significant and * Significant at 0.05 level, $* *=$ Significant at 0.01 level and $* * *=$ Significant at 0.001 level 
The interaction between variety and phosphorus level also significantly $(\mathrm{P}<0.05)$ affected the yield of fresh pod per plant at 75 and 90 DAS (Table 12). The interaction of variety Aakash and $40 \mathrm{~kg} \mathrm{P} \mathrm{ha}^{-1}$ produced the highest yield of fresh pod per plant at $75 \mathrm{DAS}(103.60 \mathrm{~g})$ and 90 DAS (128.60g) whereas Prakash at control gave the least yield of fresh pod per plant at 75 DAS (18.47g) and at 90 DAS $(29.80 \mathrm{~g})$. And Aakash also gave least yield of fresh pod per plant at control $(38.5 \mathrm{~g})$. The results of present investigation in terms of fresh pod yield per plant corroborate the findings of Nkaa et al. (2014), Nyoki et al. (2013), Ndor et al. (2012), Luse et al. (1975) and Magani and Kuchinda (2009) who reported that P fertilizers significantly affected the pod yield per plant over control treatment. Similar findings were observed in research conducted by Nkaa et al. (2014)which showed the variations among the cowpea varieties in responses of pod fresh weight per plant to phosphorus application. The result may be due to the role of phosphorus in increasing phostosynthetic efficiency resulting in proper seed formation and grain filling.

\section{Correlation and Regression}

Attributes like leaf numbers, leaf area, pod diameter, pod length, number of pods per plant were found to have statistically significant and positive correlation with yield of fresh pod (g/plant) as signified by coefficients $0.808^{* *}, 0.751 * *, 0.768^{* *}, 0.834 * *, 0.952 * *$ respectively. Number of leaves at 45 days after sowing had shown positive correlation with the yield of fresh pod (g/plant) with Coefficient of determination $\left(\mathrm{R}^{2}\right)$ value 0.653 , which shows number of leaves contributes $65.3 \%$ to the yield of fresh pod. Similarly leaf area $\left(\mathrm{cm}^{2}\right)$, pod diameter $(\mathrm{cm})$, pod length $(\mathrm{cm})$ and number of fresh pods per plant had also shown positive correlation with the yield of fresh pod (g/plant) with Coefficient of determination $\left(\mathrm{R}^{2}\right)$ value $0.563,0.590,0.695,0.905$ respectively.

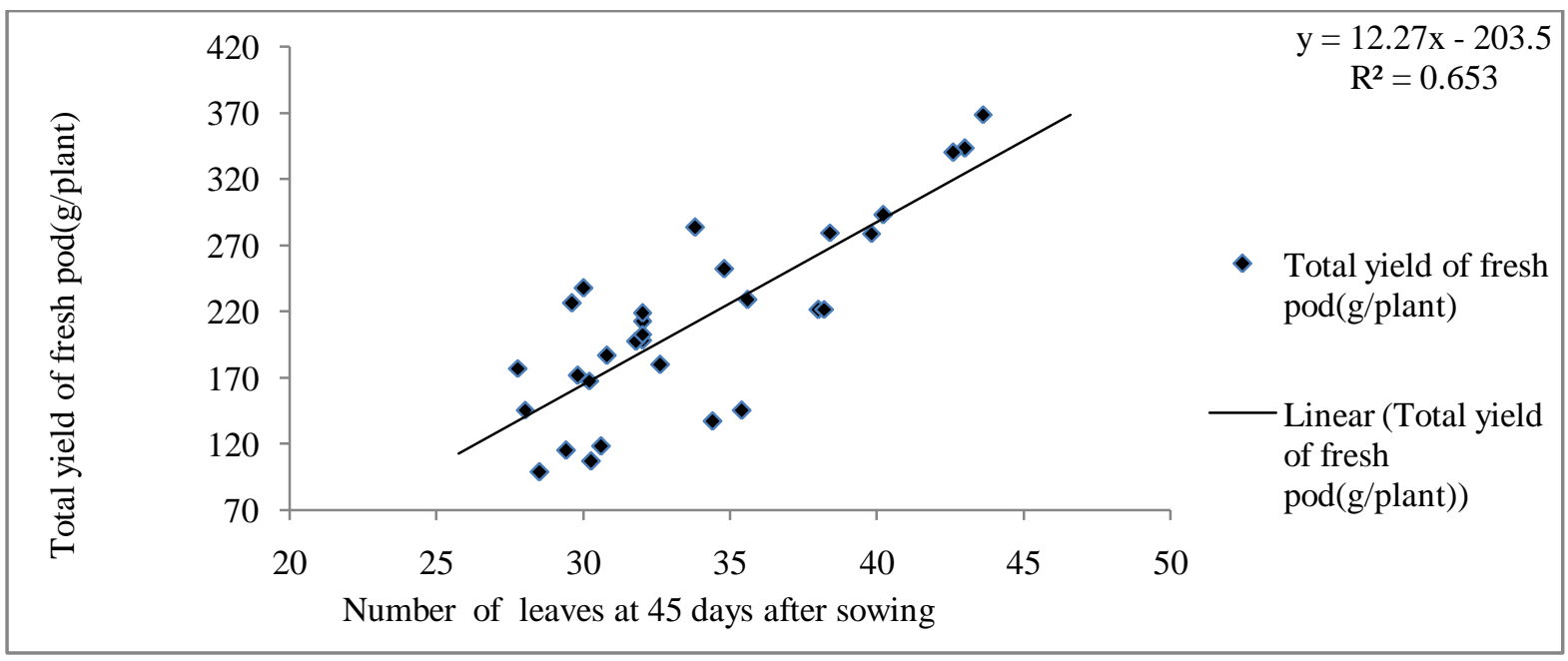

Figure 2. Effect of number of leaves at 45 days after sowing on total yield of fresh pod (g/plant) in Lamahi, Dang, Nepal during 2019 


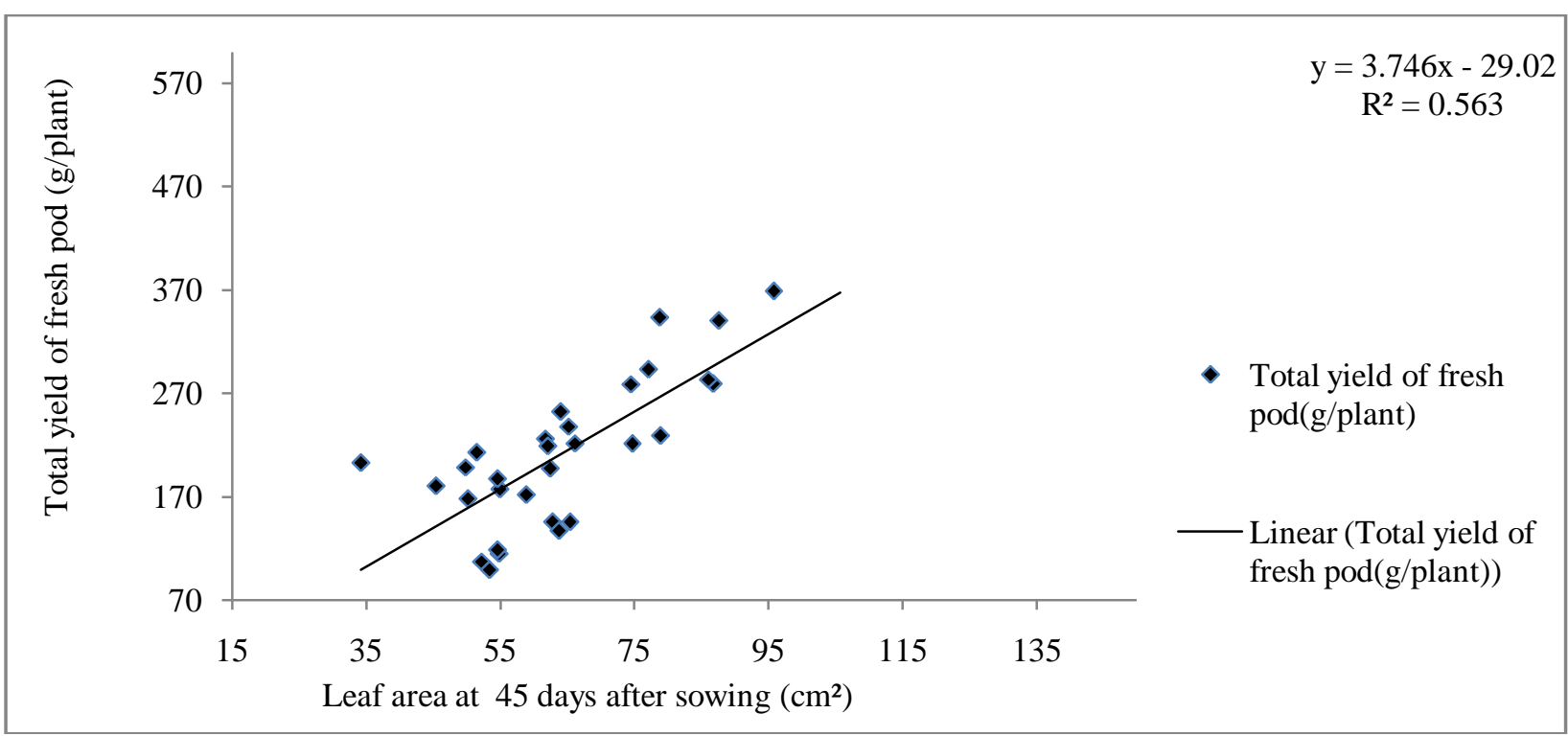

Figure 3. Effect of Leaf area $(\mathrm{cm})$ at 45 days after sowing on total yield of fresh pod (g/plant) in Lamahi, Dang, Nepal during 2019

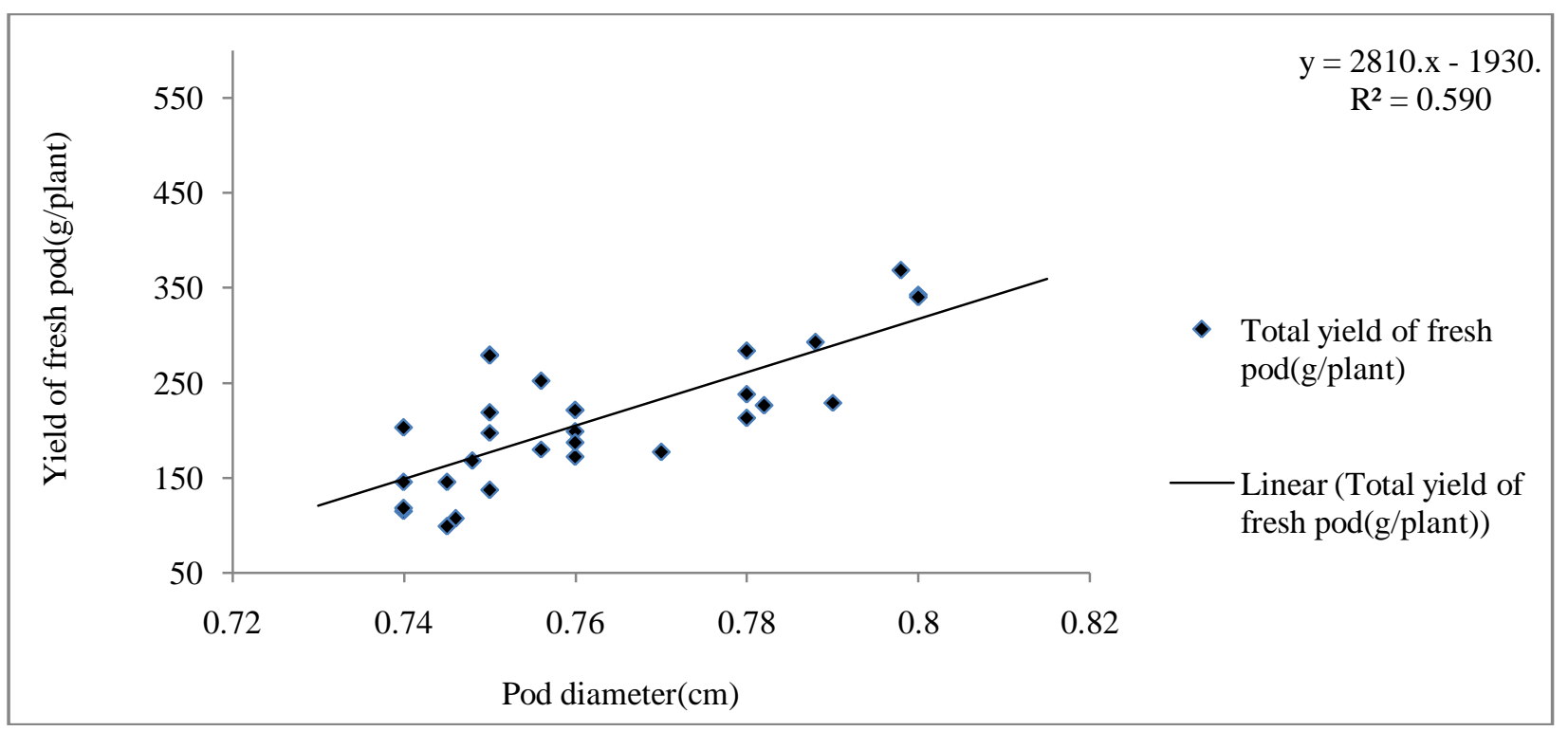

Figure 4.Effect of Pod diameter (cm) on total yield of fresh pod (g/plant) in Lamahi, Dang, Nepal during 2019 


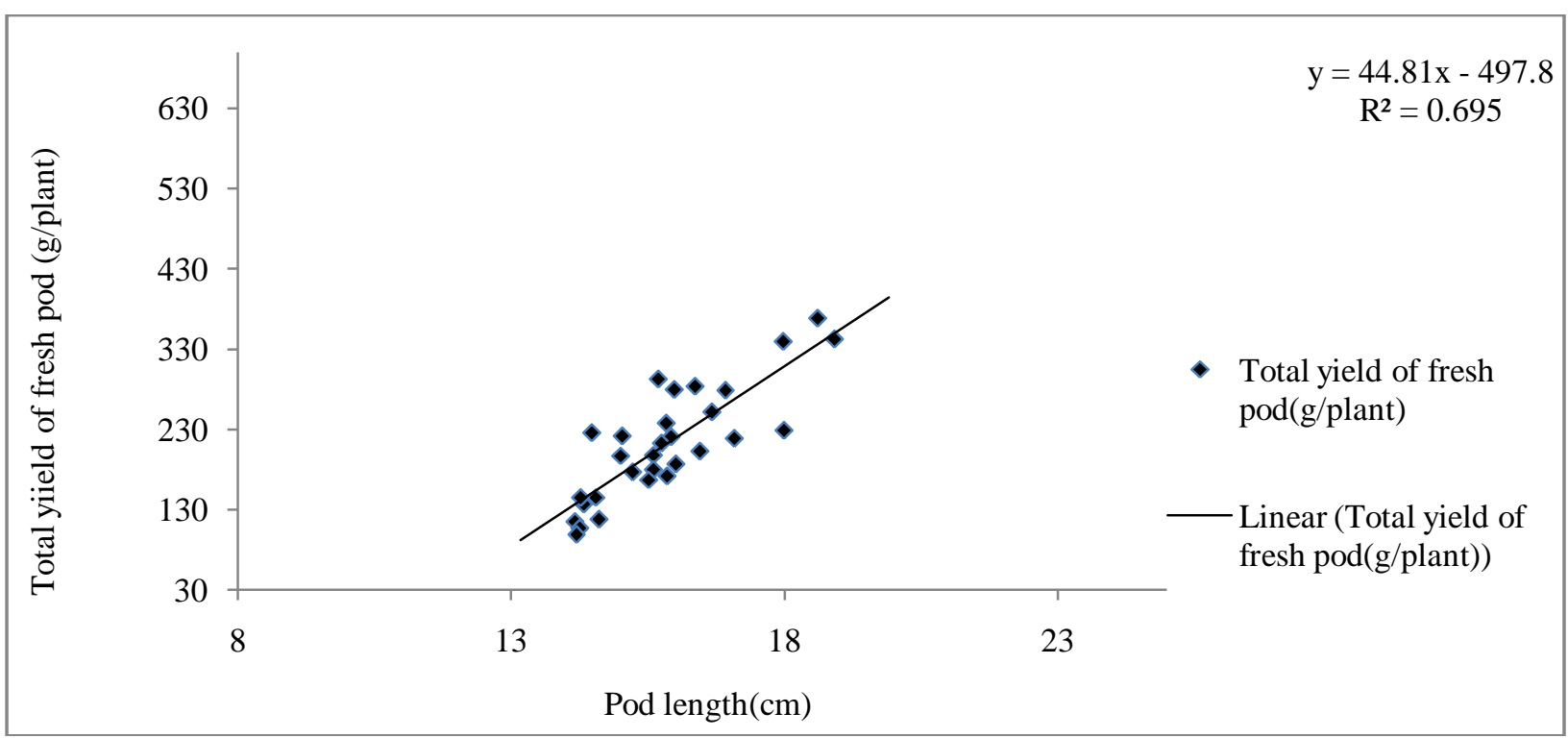

Figure 5. Effect of Pod length (cm) on total yield of fresh pod (g/plant) in Lamahi, Dang, Nepal during 2019

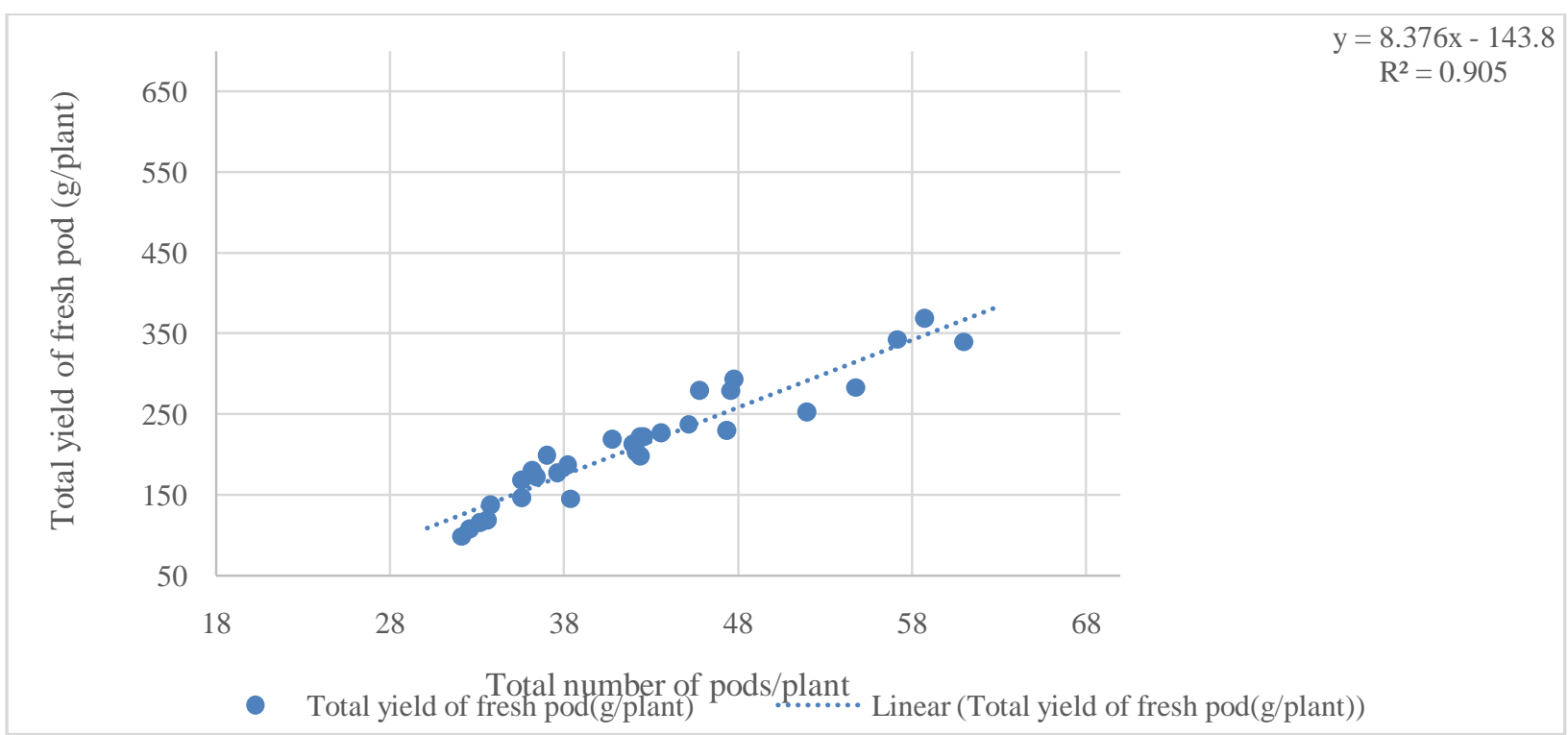

Figure 6. Effect of total number of pods per plant on total yield of fresh pod (g/plant) in Lamahi, Dang, Nepal during 2019

\section{CONCLUSION}

Variety Aakash was found to be superior in the contest of growth, development as well as yield and yield attributing character like plant height, number of leaves, leaf area, no of fresh pod. And phosphorus dose $40 \mathrm{~kg} \mathrm{ha}^{-1}$ was found to have highest impact in growth, development as well as yield attributing characters. So the use of this phosphorus dose may lead to increased production and productivity. The use of variety Aakash with phosphorus dose $40 \mathrm{~kg} \mathrm{ha}^{-1}$ may result in the satisfactory production of cowpea in the context of Dang, Nepal. 
Journal of Agriculture and Natural Resources (2021) 4(1): 62-78

ISSN: 2661-6270 (Print), ISSN: 2661-6289 (Online)

DOI: https://doi.org/10.3126/janr.v4i1.33228

\section{ACKNOWLEDGEMENT}

We express our warmest appreciation towards Prithu Technical College, IAAS for providing platform and support.

\section{Authors' Contributions}

A. Aryal and A.K. Devkota designed and performed experiment, recorded data, analysed data and wrote the paper. K. Aryal and M. Mahato supervised the experiment and edited the paper.

\section{Conflict of Interest}

The authors declare no conflict of interest regarding the publication of this manuscript.

\section{REFERENCES}

Akhtar, N., Amjad, M., \& Anjum, M. K. (2003). Growth and yield response of pea (Pisum sativum L.) to phosphorus and potassium application. Pakistan Journal of Agricultural Science, 40, 3-4.

Amba, A. A., Agbo, E. B., \& Garba, A. (2013). Effect of nitrogen and phosphorus fertilizers on nodulation of some selected grain legumes at Bauchi, Northern Guinea Savanna of Nigeria. International Journal of Biosciences,3(10), 1-7. DOI: http://dx.doi.org/10.12692/ijb/3.10.1-7

Ayodele, O. J., \& Oso, A. A. (2014). Cowpea Responses to Phophorus Fertilizer Application at Ado-Ekiti, South Western Nigeria. Journal of Applied Science and Agriculture, 9(2), 485-489.

Bawa, A. (2020). Yield Response of Cowpea to Phosphorus Fertilizer Application. Journal of Experimental Agriculture International, 42(2), 15135.DOI: https://doi.org/10.9734/jeai/2020/v42i230475

Bunker, R. R., Narolia, R. K., Pareek, P. K., Nagar, V., Chnaniya, K. K., \& Omprakash. (2018). Effect of nitrogen, phosphorus and bio-fertilizer on growth and yield attributes of garden pea (Pisum sativum L.). International Journal of Chemical Studies, 6(4), 1701-1704.

Daramy, M. A., Sarkodie-Addo, J., \& Dumbuya, G. (2017). Effect of Nitrogen and Phosphorus fertilizer application on growth and yield performance of cowpea in Ghana. Journal of Experimental Biology and Agricultural Sciences, 5(1). DOI: $10.18006 / 2017.5(1) .038 .044$

Dhital, B. K., \& Harding, A. H. (1997). Effect of planting date on phenology, yield components and grain yield of determinate cowpea varieties in the low hills of Nepal. Nepal Agricultural Research Journal, 2, 27-34.

Fatokun, C.A., Tarawali, S. A., Singh, B. B., Kormawa, P. M., \& Tamò M.(Ed.). (2002). Proceedings of the World Cowpea Conference III held at the International Institute of Tropical Agriculture (IITA). Challenges and opportunities for enhancing sustainable cowpea production. Ibadan, Nigeria. September 4-8, 2000. IITA, Ibadan, Nigeria. $424 \mathrm{p}$.

Haruna, I. M., \& Aliyu, L. (2011). Yield and economic returns of sesame (Sesamum indicum L.) as influenced by poultry manure, nitrogen and phosphorus at Samaru. Elixir Agriculture, 39, 484-488.

Ileke, K.D., Odeyemi, O. O., \& Ashamo, M. O. (2012). Insecticidal activity of Alstonia boonei De Wild powder against cowpea bruchid, Callosobruchus maculates (Fab.) 
(Coleoptera, Chrysomelidae) in stored cowpea seeds. International Journal of Biology, 4(2), 125-131. DOI : 10.5539/ijb.v4n2p125

Karikari, B., Arkorful, E., \& Addy, S. (2015). Growth, Nodulation and Yield Response of Cowpea to Phosphorus Fertilizer Application in Ghana. Journal of Agronomy, 14(4), 234-240. DOI: 10.3923/ja.2015.234.240

Luse, R.I., Kong, B. T., Fox, R. I., \& Nangju, D. (1975). Protein quality in grain legumes grown in lowland humid tropics, with special reference to West Africa. In Dam Kofoed, A. (Ed.), Fertilizer Use and Protein Production. (pp. 193-201) XIth Colloquim, International Potash Institute. 1975, Ronne-Born-holm, Denmark.

Magadlela, A., Pérez, M. A., Kleinert, A., Dreyer, L. L., \& Valentine, A. J. (2016). Source of inorganic $\mathrm{N}$ affects the cost of growth in a legume tree species (Virgilia divaricata) from the Mediterranean-type fynbos ecosystem. Journal of Plant Ecology, 9, 752761.DOI: https://doi.org/10.1093/jpe/rtw015

Magadlela, A., Steenkamp, E. T.,\& Valentine, A. J. (2015). Variable P supply affect N metabolism in a legume tree, Virgilia divaricata, from nutrient-poor Mediterraneantype ecosystems. Functional Plant Biology, 43, 287-297. DOI: https://doi.org/10.1071/FP15262

Magani, I.E., \& Kuchinda, C. (2009). Effect of phosphorus fertilizer on growth, yield and crude protein content of cowpea (Vigna unguiculata [ L] Walp) in Nigeria. Journal of Applied Biosciences, 23, 1387-1393.

Maskey, S.L., Shrestha, R. K., Shrestha, B., Tripathi, B. P., Munanakamy, R. C., Khadka, Y. G., Bhattatari, E. M., \& Shrestha, S. P. (2000). Strategy for soil fertility Research in the Hills of Nepal. Soil Science Division, NARC, Khumaltar, Latitpur,Nepal. 162p.

MoALD. (2018/19). Krishi Diary 2075. Agriculture Information and Communication Centre, Hariharbhawan, Lalitpur, Nepal. 117p.

MoALD. (2019). Statistical Information on Nepalese Agriculture. Government of Nepal, Ministry of Agriculture and Livestock Development, Planning and Development Cooperation Coordination Division, Statistics and Analysis Section, Singha Durbar, Kathmandu, Nepal.

Muhammed, A.A., Oumar, S. K., Mukhtar, A. A., Sharifai, A. I., \& Kura, H. N. (2013). Response of cowpea (Vigna unguiculata (L) Walp) varieties to difference sowing dates and irrigation at Kadawa. In 13th National Irrigation and Drainage Seminar, A.B.U. Zaria. (pp. 49-51)

Namakka, A., Jibrin, D. M., Hamma, I. L., \& Bulus, J. (2017). Effect of Phosphorus levels on Growth and Yield of Cowpea (Vigna unguiculata (L.) Walp) in Zaria, Nigeria. Journal of Dryland Agriculture, 3(1), 85-93. DOI: https://doi.org/10.5897/JODA.9000005

NARC. (2002). Annual report 2001/2002. National grain legumes research program, Rampur, Chitwan, Nepal.

Ndakidemi, P.A., \& Dakora, F. D. (2007). Yield components of nodulated cowpea (Vigna unguiculata (L.) Walp) and maize (Zea mays) plants grown with exogenous phosphorus in different cropping systems. Australian Journal of Experimental Agriculture, 47(5), 583-590. DOI: https://doi.org/10.1071/EA05274

Ndor, E., Dauda, N. S., Abimuku, E. O., Azagaku, D. E., \& Anzaku, H. (2012). Effect of phosphorus Fertilizer and Spacing on Growth, Nodulation Count and Yield of Cowpea (Vigna unguiculata (L) Walp) in Southern Guinea Savanna Agroecological Zone, Nigeria. Asian Journal of Agricultural Sciences, 4(4), 254-257 
Nkaa, F.A., Nwokeocha, O. W., \& Ihuoma, O. (2014). Effect of phosphorus fertilizer on growth and yield of cowpea (Vigna unguiculata). IOSR Journal of Pharmacy and Biological Sciences, 9, 74-82.

Nyoki, D., \& Ndakidemi, P. A. (2013). Economic benefits of Bradyrhizobium japonicum inoculation and phosphorus supplementation in cowpea (Vigna unguiculata (L) Walp) grown in Tanzania. American Journal of Research Communication, 1(11), 173-189.

Omueti, J. O., \& Oyenuga, V. A. (1970). Effect of phosphorus fertilizer on the protein and the essential components of the ash of groundnuts and cowpeas. West African Journal of Biology and Applied Chemistry, 13(1), 14-19.

Pandey, S. (2010). Response of lentil (Lens culinaris Medikus) to lime and phosphorus applications in acid soils of Chitwan, Nepal. M.Sc. Thesis, IAAS, Tribhuwan University, Nepal. 29p.

Pérez, F. M. A., Calvo, E. M., Rodríguez, S. J., \& Valentine, A. (2017). Differential growth costs and nitrogen fixation in Cytisus multiflorus (L'Hér.) Sweet and Cytisus scoparius (L.) Link are mediated by sources of inorganic N. Plant Biology, 19, 742748.

Pérez, F. M. A., Calvo-Magro, E., \& Valentine, A. (2016). Benefits of the symbiotic association of shrubby legumes for the rehabilitation of degraded soils under Mediterranean climatic conditions. Land Degradation and Development, 27, 395405.

Singh, A., Baoule, A. L., Akmed, H. G., Aliyu, U., Sokoto, M. B., Alhassan, J., Musa, M., \& Haliru, B. (2011). Influence of phosphorus on the performance of cowpea (Vigna unguiculata (L) Walp) in Southern Guinea Savanna agroecological zone, Nigeria. Asian Journal of Agricultural Science, 4, 254-257.

Stevens, G.G., Pérez, F. M. A., Morcillo, R. J. L., Kleinert, A., Hills, P., Brand, D. J., Steenkamp, E. T., \& Valentine, A. J. (2019). Roots and nodules response differently to $\mathrm{P}$ starvation in the Mediterranean-type legume Virgilia divaricata. Frontiers in Plant Science, 10, 73.

Thosago, S. S. (2015). Response of selected cowpea lines to low soil phosphorus and moisture stress conditions at Ukulima farm in Limpopo province. M.Sc. Thesis, University of Limpopo, South Africa. 